\title{
Archipel
}

A RCHIPEL Études interdisciplinaires sur le monde insulindien

95 | 2018

Varia

\section{Contemporary Islamic Movement, Popular Culture and Public Sphere in Indonesia: The \#IndonesiaTanpaJIL Movement}

Mouvement islamique contemporain, culture populaire et sphère publique en Indonésie: le mouvement \#IndonesiaTanpaJIL

Imam Ardhianto

URL: https://journals.openedition.org/archipel/652

DOI: 10.4000/archipel.652

ISSN: 2104-3655

Publisher

Association Archipel

\section{Printed version}

Date of publication: 29 June 2018

Number of pages: 151-171

ISBN: 978-2-910513-79-5

ISSN: 0044-8613

\section{Electronic reference}

Imam Ardhianto, "Contemporary Islamic Movement, Popular Culture and Public Sphere in Indonesia: The \#IndonesiaTanpaJIL Movement", Archipel [Online], 95 | 2018, Online since 01 July 2018, connection on 27 August 2021. URL: http://journals.openedition.org/archipel/652 ; DOI: https:// doi.org/10.4000/archipel.652 


\section{Contemporary Islamic Movement, Popular Culture and Public Sphere in Indonesia: The \#IndonesiaTanpaJIL Movement}

\section{Introduction}

On February 14, 2012, at the Hotel Indonesia traffic circle in Jakarta, dozens of pro-democracy, feminists and LGBT-rights activists staged a rally to call for the disbandment of the hard line Islam Defenders Front (FPI) with a slogan: "Indonesia Tanpa FPI" (Indonesia without FPI). The rally was held in response to a series of violent attacks spearheaded by FPI members against the followers of Ahmadiyah, a minor Islamic denomination deemed heretical by the Majelis Ulama Indonesia (Indonesian Ulema Council). The political consolidation and arrangements for the rally were made on Twitter after social media users introduced the hashtag \#IndonesiaTanpaFPI. The hashtag trended swiftly, as it was used as a keyword for multiple politico-religious discourses on the plight of the Ahmadiyahs involving the urban middle class in Jakarta and other major cities. In a symbolic move, the protestors showcased a mock gift with a satirical message: "Valentine Gift for Habib Riziq, the Leader of FPI." Their demand, however, was clear: the government should disband the FPI, for the group had betrayed the state ideology of Pancasila and the principle of Bhineka Tunggal Ika (Unity in Diversity).

1. Department of Anthropology, University of Indonesia.

2. The FPI (Front Pembela Islam) is a militia or vigilante group founded in 1998 by Habib Riziq Shihab (Feillard \& Madinier 2011). 
A few weeks later, on March 9, 2012, another rally was staged by a different group at the same location to counter the $\mathrm{JIL}^{3}$-led movement. This rally was initiated by social media users who were deeply concerned by the growing popularity of the \#IndonesiaTanpaFPI campaign, which they viewed as a sign of the growing clout of JIL activists and their religious views in the public sphere. They later promoted a new counter hashtag: \#IndonesiaTanpaJIL (IndonesiawithoutJIL). \#IndonesiaTanpaJIL supporters are different from typical Muslim activists. Those who took part in the rally denouncing JIL were independent artists — punk and trashmetal musicians - and young urban entrepreneurs who met online to challenge the \#IndonesiaTanpaFPI movement. ${ }^{4}$ One of the most prominent figures from this group was Akmal Syafril ${ }^{5}$, who delivered a speech explaining why they needed to hold a counter rally and launch the \#IndonesiaTanpaJIL movement.

\footnotetext{
"JIL activists are currently playing a dominant role on the Internet. Every day, Indonesian youth read their tweets. One of [JIL activists] told us that a kiss between a [Muslim] woman and man is not forbidden during fasting. The other said that a kiss is just like alms. Another JIL activist, Guntur Romli, said that Islam is an oplosan. ${ }^{6}$ Do we need to remain passive against this movement? Their action in cyber world has prompted Indonesian youth to stand up to defend their religion. Students, musicians, Muslim activists, and even housewives are now aware of how dangerous they are. The culmination of their movement occurred on February 14, 2012, when they all stood here at the same place with only 40 people that include transvestites, sinners and pornography supporters. The media said the people of Indonesia rejected the FPI. Are all Indonesian people transvestites? Is it true that all Indonesians are pornography activists? We should say no to JIL. Allahu Akbar!! Disband JIL!! Indonesia without JIL!!"
}

3. JIL is an abbreviation for Jaringan Islam Liberal, a civil-society organization created to promote a space of dialogue about Islamic values and liberal interpretations of Islam in Indonesia. It was created by a young generation of scholars who were familiar with the agenda of democracy and the rights of minority groups. The members of this organization are strongly connected with previous famous inclusive Islamic intellectuals such as former presidents Abdurrahman Wahid and Nurcholis Madjid.

4. My first impression upon seeing their rally was that they represented different social backgrounds compared to other Islamic activists, marked by their appearance and casual manner in contrast with Forum Umat Islam and the FPI who happened to be at the same rally. As soon I had the chance to interview a few members involved in the first public demonstration afterward, they acknowledged that they came from different professions in Jakarta, including rock musician, film artist, event organizer, students, and clothing design entrepreneurs. This was confirmed as well during my discussion at the first national congress of this movement at Cikole Lembang in 2012.

5. Akmal Syafril was born in Jakarta in 1981. He has a Civil Engineering educational background from the Institut Teknologi Bandung (ITB). He said during the interview that he was only occasionally involved with student Islamic movements. In 2007, he received a scholarship from Dewan Dakwah Islam Indonesia (DDII) and the Badan Amil Zakat National Foundation to continue his master's degree at Universitas Ibnu Khaldun, Bogor. He wrote a thesis entitled "Studi Komparatif antara Pluralisme Agama dengan Konsep Hubungan Antar Umat Beragama dalam Pemikiran Buya Hamka" (Comparative Study of Religious Pluralism with Inter-Religious community of Buya Hamka." After completing his master's degree, he has been a contributor to various Islamic journals promoting his ideas of the critique of Liberal Islam at numerous events.

6. Oplosan is a metaphor used by JIL activists to describe religion as a mixture of various influences. Colloquially, it usually refers to liquors that are mixed with chemical substances. 
Following the counter-demonstration, the \#IndonesiaTanpaJILhashtag ${ }^{7}$ was massively disseminated via social media and during the following weeks similar rallies, also organized via social media, were held in other cities such as Bandung, Bogor, and Makassar. In March 2013, the Indonesian Bigots Community (Komunitas Bigot-Bigot Indonesia ${ }^{8}$ ) and One Finger Community, both started to be active on social media, ${ }^{9}$ creating a Twitter account,@TanpaJIL, to serve as their main propaganda tool. Surprisingly, while the \#IndonesiaTanpaFPI discourse slowly faded on Twitter, the \#IndonesiaTanpaJIL discourse gained more attention in the following months. In a day, almost 3,000 people joined the \#IndonesiaTanpaJIL group page. Over the next seven months, this page managed to get 33,048 members who were regularly updated about all the Indonesia Tanpa JIL activities. The Twitter account at the time had 15,041 followers.

The emergence of \#IndonesiaTanpaJIL has strong connections with the long history of fragmentation and ideological rivalries between Islamic groups in Indonesia. \#IndonesiaTanpaFPI, supported by JIL activists, is a movement which genealogically could be traced to the liberal and inclusive Islamic movement of the 1980s that was strongly associated with Nadhlatul Ulama, the largest Muslim organization in Indonesia. The other, \#IndonesiaTanpaJIL is influenced by the radical ideas of one of the currents of thought claiming Masyumi heritage, and by its contemporary ideological progeny such as Dewan Dakwah Islamiah Indonesia, Partai Keadilan Sejahtera or the Justice and Prosperous Party, and other emerging trans-national Islamic movements such as the Salafist and Hizbut Tahrir movements. \#IndonesiaTanpaJIL is the latest form of the Islamic movement, taking its place in the long history of political contestation over the role of the religious in the public sphere in Indonesia.

Born into the world of social media, this latest generation of Indonesian Muslim activists has taken on a new cultural form. Regardless of their religious convictions - some of them were Salafists and members of the Tarbiyah Movement - they have been able to use popular culture and other Western social forms that were commonplace in social media and urban public spaces in Indonesia. Even though the main discourse of their slogans was similar to that of typical radical Muslims (that Muslims are now facing the threat of

7. Hashtag is a feature on Twitter that enables users to create coding of their tweets by using the symbol "\#" as the first character in front of their name code. It is used to make it easier for Twitter users to find trending topics on social media websites.

8. KBBI (Komunitas Bigot-Bigot Indonesia) is a group that originated in online discussions, mainly on Twitter. The main topic of their discussions is the threat of the Liberal Islam Network or JIL and how it affects the beliefs of the Indonesian Muslim community or ummah. It was established in 2010 and later, in 2012, several of its members joined the \#IndonesiaTanpaJIL movement.

9. In this context, "social media" refers to all kinds of digital technology that connects people via the Internet and enables them to share information from text, visual, and audio resources. In this study I focus on Twitter, Facebook, blogs, websites and YouTube. 
Zionism and Western-secular forces in Indonesia), they articulated it in a more attractive way by wearing fashionable T-shirts, promoting their slogans in English and even wearing jeans while listening to hip-hop music, rather than wearing Arabic-style robes and listening to nasyid (Islamic gospel songs). These transversal cultural symbols, along with the accompanying discourse, have become the hallmark of a new kind of Islamic movement in Indonesia.

Islamic movements that appeared in many public demonstrations reflected a changing form of political Islam in Indonesia: in response to the political changes and the weakening of Islamic parties, they decided to alter their political articulation to the public sphere. Presently, there are alternative channels to articulate Islamic discourse such as the internet and public demonstrations that have been localized in particular cities and in certain class segments. This phenomenon was influenced by the development of media technology, which has increased rapidly over the past ten years. It is also closely linked to the emerging post-authoritarian era of cultural autonomy and the open access to media and infrastructures in order to promote one's ideology in new mass media. Further, the significant changes, which are the foundation of this article, also mark the era of popular Islam and the considerable trend of accelerated mixing of popular-culture commercialization and conservative Islam in Indonesia (Fealy \& White 2008; van Bruinessen 2013), which reveals a new conservative piety that has taken on a Western cultural form.

In contemporary Indonesia, the rise of Islamic movements in social media is marked by the \#IndonesiaTanpaJIL hashtag which is heavily influenced by the new era of internet-based propaganda and discourses. Created in 2013 and following a similar movement in a large part of the world such as Spain, Tunisia, Egypt, and also America (Lim 2012) this social movement is an exemplary case of the use of media technology, printed matter, and popular culture to adapt to the changing landscape of mass media infrastructure among religious groups and to produce religious audiences (Hirschkind 2006; Hirschkind \& Larkin 2008; Meyer \& Moors 2006; Salvatore 2007). Their appearance on the social media scene brings forward former Islamist propaganda as their main discourse, since they still link their micro-blog discourse with Islamist websites, whether they have Salafist, Tarbiyah, or other Islamist ideological affiliations. But these historical roots also have their own ruptures since they also interact with the context of the changing public sphere in the social media landscape of Indonesia, which requires them to incorporate the new style of propaganda. In this context, this social movement is strongly related to the influences of popular culture and the new middle-class reader, who was previously not frequently involved in Islamist politics in Indonesia.

The growing social apprehension toward liberal interpretations of Islam is now worrying urban Muslims and taking on a cosmopolitan face. This phenomenon may be seen as a result of tension between the civil Islam 
characteristics of Indonesian Muslims (Hefner 2000) and the temptation toward radicalism (Feillard \& Madinier 2011) that is now being experienced by the Indonesian middle class within the context of Islamic commercialization (Rakhmani 2017). Furthermore, this phenomena emerged as a result of a combination between the middle class, tempted to accommodate a populist kind of Islam (Hadiz 2014), and the latest generation of puritan/radical Islamic activists, who joined the debates on contemporary religious issues from within a new medium of propaganda. This characteristic has been the most significant aspect in the transformation of the ideology and cultural form of the contemporary Islamic movement in Indonesia-media technology. What is the socio-historical basis of these phenomena? What is the implication of this transformation for the cultural form of the Islamic movement and their political effects in the public sphere?

\section{Contemporary Urban Muslims in Indonesia: Socio-Historical Back- ground of \#IndonesiaTanpaJIL Movement}

\#IndonesiaTanpaJIL is a movement that arose on March 5, 2012, from the coalition of various internet-based communities in response to the rise of the \#IndonesiaTanpaFPI discourse, popularized by liberal-Islam activists in Indonesia. The \#IndonesiaTanpaJIL movement initially consisted of people from various religious backgrounds - adherents of different Islamic ideologies such as Hizbut Tahrir, Tarbiyah, Salafi, and even laymen who were only starting to develop an interest in Islamic issues. They also came from different professions. Notably, most were middle class, and lived in urban centers such as Greater Jakarta, Bandung, Solo, and Makassar. In short, most were middle-class urban youth. According to their main proponent, Akmal Syafril, the initial discussion that brought them together happened on Twitter in late 2012, started by the popular term "Komunitas Bigot-Bigot Indonesia," which was used to describe them. Connected via the Internet, this group continued to conduct their discussions on Twitter and through a mailing list. They all share a similar concern: the fear that Western ideologies have infiltrated the Islamic community (Ummat) in Indonesia. According to them, this was due to the rising stature of public intellectuals who were heavily influenced by Western scholars. Most of these intellectuals had been educated in European and American universities, and regularly published their Western-influenced discourses in the mass media. The term "Bigot" in the group's name came in reaction to the label the "Liberal Islam activists" applied to them because of their opinions regarding the role of the State in regulating Islamic religion in the public sphere as well as their attitude in social media toward religious minorities such as the Ahmadiyah and Syiah in Indonesia.

Nowadays, the two main figures in the \#IndonesiaTanpaJIL movement are Hafidz-Ary and Akmal Syafril. Both are graduates of Institut Teknologi 
Bandung (Bandung Institute of Technology). Hafidz-Ary is an alumnus of the Salman Mosque organization in ITB, while Akmal only became an Islamic activist after he graduated in 2004. Akmal was involved in a series of studies developed by Adian Husaini at the Jakarta-based INSIST (Institute of Islamic Thought and Civilization) and the University of Ibnu Khaldun, Bogor. INSIST is an organization that focuses on Islamized sciences, and its proponents openly admit to being influenced by the thoughts and teachings of a Malaysian intellectual, Syed Naquib Al Attas. ${ }^{10}$ In 2013, INSIST leader Adnin Arnas actively supported \#IndonesiaTanpaJIL members by giving lectures during various events organized by the community. Other figures who were strongly involved in the first phase of this movement included Onbak from a trash-metal music band named Purgatory, and Mehdy, a member of Melody Maker, a band in the underground music community that introduced Islamic discourse and warned their fan base against the dangers of liberalism. Other artists involved included Ucay from the indie-rock band Rocket Rocker, a former host of Asia Music Television Broadcasting (MTV station) Arie K Untung and national film actor Fauzi Badilah. Along with 50 other members, they were pioneers of this social movement condemning the widespread influence of the Jaringan Islam Liberal (Liberal Islam Network) in Indonesia.

As a Tarbiyah alumni stated, most of the people in the movement who came from a non-Islamic activist background had been newly exposed to issues of Islam and the threats it is facing in Indonesia, and did not have any form of clear connection to Islamic activism. Mehdy and Onbak, who came from the underground rock music community, had different historical interests compared to Hafidz-Ary or Akmal. They were keen on the conspiracy theory that the Illuminati ${ }^{11}$ and Freemasons ${ }^{12}$ would conquer Indonesia. These musicians, who

10. INSIST and Ibnu Khaldun University have a close connection to CASIS (Centre for Advanced Studies on Islam, Science, and Civilization) at the UTM (Universiti Teknologi Malaysia). CASIS was founded by Professor Dr. Wan Mohd Nor Wan Daud who was strongly influenced by Syekh Naquib Al Attas' intellectual perspective on Islam, Western civilization and secularism. His perspective identifies the problems of Western civilization and secularism influences on Muslim society, which resulted in incompatibility and the violation of Islamic ethics (For further details see, Al-Attas, Muhammad Naguib, Islām and secularism, Kuala Lumpur, Muslim Youth Movement of Malaysia, 1978). This idea influenced, INSIST, with regard to their critical, and often hostile, argument toward Indonesian liberal Islam activists on the subject of Islam, the state, and secularism in Indonesia.

11. Famous among conspiratorialists, Illuminati (plural of Latin illuminatus, "enlightened") is a name given to several groups, both real and fictitious, which are supposedly secret and aim to oppose religious influence over public life, and abuses of state power. Historically, the name usually refers to the Bavarian Illuminati, an Enlightenment-era secret society founded on 1 May 1776.

12. Also famous among conspiratorialists, the Freemasons were a secret society that developed historically in various regions of Europe, and has been responsible for major political and religious events in the world. However, it should be noted that members of Komunitas Salam Satu Jari (One Finger Community) have no knowledge of the details of its historical roots and are more interested in its connection to Zionism and Liberal Islam in Indonesia. Komunitas 
belonged to the Komunitas Salam Satu Jari (literally One Finger Movement), represented a subset within the \#IndonesiaTanpaJIL movement.

Most of the members of Komunitas Salam Satu Jari were recruited from clubs frequented by underground music fans in Jakarta - Purgatory, Melody Maker, and Tengkorak being the famous bands that were actively involved in the community. It also formed close relations with independent clothing and apparel distribution companies (distro), such as Islamic Clothes United and Mujahid distro, which frequently displayed their products at various Jakarta clothing exhibitions. This online organization, which built its network through Facebook, mailing lists, and Twitter, was supported by pre-existing networks established by punk metal music productions and shows. Some bands regularly held Islamic study groups with various Islamic preachers from Pondok Gede (Bekasi), Pancoran (South Jakarta), and Cileduk (Tangerang). Their studies were usually reflected in their lyrics, band symbols, musical sounds, and performances. These were then imitated by the fan base that usually attended their performances, with the aim not only to enjoy the music but also to be reminded of their religious beliefs and corresponding political attitude toward world orders dominated by the threats of universal evils such as Zionism, Illuminati, and Freemasons. Their discourse usually replicated that of the Intifadah Hamas Movement in their struggle against the Zionists in Palestine. They perceived the emergence of JIL activists (whose ideas on national mass media are widely published) as confirming their fears. In their eyes, the rise of JIL is the manifestation of those universal evil powers in Indonesia; it is aimed at weakening the power of Ummat through their political-economic resources. Nevertheless, JIL's emergence also forged a common ground, which they now share with their fellows from Tarbiyah (Usroh ${ }^{13}$ and ROHIS ${ }^{14}$ alumni).

The defining moment that marked their first affirmative action against the universal evils of global power they fear was their organization of the \#IndonesiaTanpaJIL demonstration. This first offline consolidation happened a week after another protest, the \#IndonesiaTanpaFPI demonstration, which condemned the Islam Defenders Front actions toward Ahmadiyah communities in various places in Indonesia. The \#IndonesiaTanpaJIL movement came out into the public eye for the first time at this demonstration. Members of the Islam

Salam Satu Jari is a fan community consisting of several underground trash-metal bands in Jakarta and other cities in Indonesia that are focused around Islamic values. The bands have assembled on the basis of a shared belief in variants of the conspiracy theory about the role of Illuminati and Freemasons in degrading the moral life of Muslims in Indonesia.

13. Tarbiyah Movement study groups usually consist of a maximum of five persons, with one leader called the murabbi. One group connects with larger groups and creates a system of group consolidation. Historically, this movement was born in Egypt under the leadership of Imam Hasan Al Banna.

14. This is an acronym for Rohaniawan Islam, an Islamic religious organization at the high-school level in Indonesia. It is well known as the place where Tarbiyah/Hizbut Tahrir recruits cadres. 


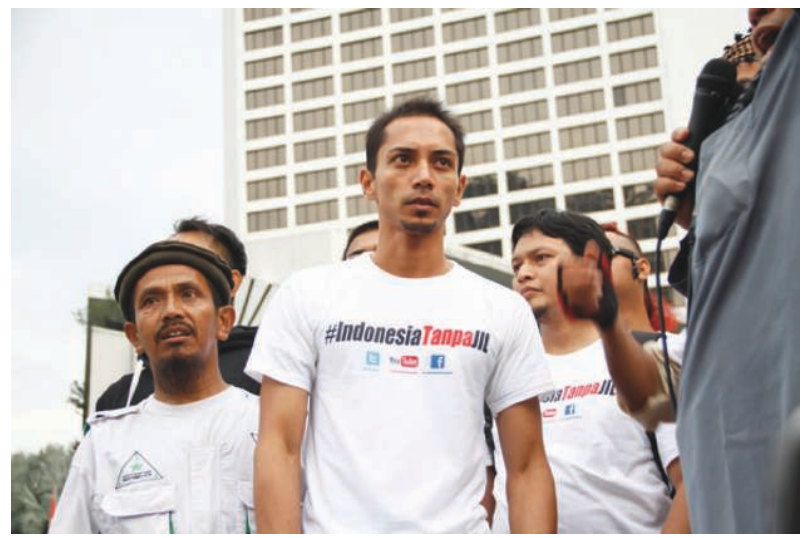

Fig. 1 - Fauzi Badillah (center), a famous film star and Akmal Syafril in the first demonstration of \#IndonesiaTanpaJIL with FPI members (source: http://jogjadistromuslim.blogspot.de/2013/04/indonesia-tanpa-jil.html)

Defenders Front themselves joined the protest, as well as the Front Ummat Islam. Fifty people who previously had mainly interacted through social-media platforms such as Twitter and e-mails came together to rally at this offline event. One of the ways protesters involved in the demonstration rendered themselves visible was by wearing T-shirts printed with \#IndonesiaTanpaJIL slogans. The design of the T-shirt was markedly popular in its characteristics. With their T-shirt and jeans, their appearance stood out in contrast to that of their fellow protesters, namely members of the Islam Defenders Front who wore Muslim robes. Some of the artists/musicians involved in the movement also sported very distinct looks with their mohawk ${ }^{15}$ and/or other kinds of "rockstar" hairstyles.

After the demonstration, they created the Twitter user account @TanpaJIL. The name chosen for the account made their main discourse self-explanatory, i.e., using social media as a resistance against JIL activists in Indonesia. They created a Facebook page under the name \#IndonesiaTanpaJIL; on the day of the launch, 3,000 people started following the movement's updates. The number rose to 70,000 the very next day. As of May 2014, the Facebook page had 57,866 Indonesian followers, while the Twitter account has gained 47,600 followers. They claim they are an intellectual movement that endeavors to unite various Islamist groups in Indonesia through a mutual interest in countering liberal Islam in the Indonesian public sphere.

15. The mohawk (also referred to as a mohican) is a hairstyle in which, in the most common variety, both sides of the head are shaven, leaving a strip of noticeably longer hair in the center. It is becoming the trademark of punk and rock music identity in Indonesian contemporary music lifestyle. 
One of the reasons why their Facebook page saw remarkable growth in its number of followers was because of their alliance/affiliation with other communities such as Komunitas Salam Satu Jari.

The organization structure of this movement was very loose and largely depended on urban proponents' self-initiatives across Indonesia. Those who were interested in becoming involved could do so through various venues: they could pursue active participation online, attend protests/demonstrations or other public actions, organize public lectures in mosques/universities, and distribute flyers about the community's events. A national coordinator was elected for the first time in March 2012: he was tasked with managing organizational issues and ensuring the increasing in magnitude of the discourse through coordination with chapters throughout the country. In 2012, the group already had 14 chapters located in several cities in Sumatera, Java, Nusa Tenggara Barat, and Sulawesi. As mentioned by the coordinator, they have now expanded to 21 chapters nation-wide, which include not just city-based chapter groups, but also groups affiliated with higher education institutions such as \#ITBtanpaJIL. However, we should be aware that the recognition of a chapter often only needs few people to be accepted to qualify as a new chapter, meaning that some are supported by a weak network base. There are no detailed statistics available to confirm the exact number of active members who are currently closely involved in this movement, but the Internet traffic and social media statistics indeed suggest increasing participation of urban youth in their discourses.

\section{\#IndonesiaTanpaJIL: Political Consolidation}

The emergence of the \#IndonesiaTanpaJIL movement shows that social media influence can have a profound impact as online discourse can lead to real political consolidation. In the case of this movement, discourse was not merely kept confined to long conversations and a series of disputes on discussion websites; it also found an outlet in public action. It was translated into tangible material for agitation and propaganda of their movement in the form of leaflets, websites, YouTube videos, T-shirts, and so on. This propaganda was a strategic way of engaging a discourse of mainstream national mass media and popular discourse regarding liberal Islam in Indonesia, spread through social media. The discourse the movement engaged in was closely connected to the latest circulating news on subjects related to the regulation of religion and citizenship. Before entering and becoming engaged in public debates, some of the members gather discourse material from books, scientific journals, university lectures, and TV-show discourse, all of which are available to the public. In particular, they pay attention to certain public figures whose thoughts on liberal Islam appear frequently in the mainstream mass media, especially opinions held by JIL activists. 
Frequent publications by prominent JIL figures on news websites and national magazines and newspapers such as Tempo and Kompas, to promote a liberal interpretation of Islamic ideas in Indonesia was arguably the main reason why some \#IndonesiaTanpaJIL activists came up with their own propaganda. The first article that marked the beginning of the movement was Ulil Abshar Abdalla's article in Kompas on November 18, 2002, titled "Refreshing Islamic Interpretation." The article explains the urgency for Muslims in Indonesia to open up to alternative interpretations and dialogue, and a pluralist attitude in understanding religiosity in Indonesia. This particular article reached a wide audience as it was discussed and debated by various Islamic community groups via their mailing lists and on websites. As JIL's posture gained momentum, fear developed among \#IndonesiaTanpaJIL members that the current presentation of Indonesian Islam in the public sphere was misleading. This provided \#IndonesiaTanpaJIL with a strong rationale to start their own movement and focus on political consolidation so as to counter JIL's popular discourse in the mass media. INSIST, ${ }^{16}$ an institution supported by Adian Husaini (also a DDII activist), actively backed Akmal Syafril in producing books that respond to the JIL network's ideas in the mass media and on the internet. Jealousy over JIL activists' popularity when they attain positive reputations and gain greater acceptance from social-media users in Indonesia seems to give the \#IndonesiaTanpaJIL additional momentum.

In response to the threat of Westernization, the \#IndonesiaTanpaJIL movement put a lot of thought into the vital aspects of media propaganda and handled them with great care. During their first National Congress (SilaturahmiNasional ITJ) on the 11th of November 2012, they mentioned six media instruments that are important in order to create counter-discourse actions to destabilize JIL discourse in social media, as well as in the national media. One of their coordinators, Hizbullah, said that:

First, it is imperative to create offline media. Example of offline media forms are saleable goods/products like T-shirts, jackets, and others merchandise ${ }^{17}$ that inform people of our social media account and our movement's name. It's like branding. The second is printmediated output, such as leaflets, pamphlets, and books. Third is media broadcasting such as radio shows. We have to persuade radio owners to create our own air-session that explains the problem of JIL, just like previously begun by ITJ at Solo. Fourth, is face-toface promotion such as appearance in TV talk shows, or events happening in public places such as city squares or malls. Fifth, the traditional way is to come to every public event in various cities and give out posters and leaflets. Last but not least is online media. ${ }^{18}$

The media strategy was the result of their seven-month movement evaluation

16. Most of its founders are affiliated with Dewan Dakwah Islam Indonesia (DDII), which has an Islamic revivalist ideological orientation.

17. The movement prints the \#IndonesiaTanpaJIL hashtag on T-Shirt, jackets, and flyers.

18. Hizbullah, personal observation at the national congress of \#IndonesiaTanpaJIL at Cikole, Lembang, Bandung, November 11, 2012. 
which began in February 2012. The main problems as well as the potential of the movement were identified at the National Congress. \#IndonesiaTanpaJIL is seriously involved in several aspects of media propaganda. At the ITJ National Gathering, they listed six media devices that should be used in an interrelated network of discursive circulation and propaganda. This media propaganda strategy was built upon reflection and evaluation of the \#IndonesiaTanpaJIL movement's previous year's activities. It identified the potential and the problems in their attempt to take over as the public's voice ("the voice of the people") through social media. It had them consider important strategies. All of this also could not be separated from the dynamics of accessing an audience in their previous propaganda. The most important lesson, according to some informants, could be seen from the response to the coverage by Metro TV, a national television station. On September 14, 2012, Metro TV broadcasted a report on "Patterns of Young Terrorist Recruitment." The news created restlessness among the \#IndonesiaTanpaJIL community, as most of its members are from the Tarbiyah Movement and Hizbut-Tahrir. Both recruit cadres mostly from mosques and Rohis (Rohaniawan Islam), a formal Islamic student organization at high schools, and both were described by Metro TV as places for cadre recruitment by terrorist activists.

Another emblematic case, apart from the protest against MetroTV, pertains to the Ahmadiyah phenomenon. Intense dissenting public opinions about the Ahmadiyahs on social media were first triggered by a demonstration held by JIL figures alongside some NGO activists, broadcasted on social media with the hashtag \#IndonesiaTanpaFPI. In 2012, there was an escalation of violent acts against minority groups by the Islam Defenders Front. The issue grew out of the violent actions against minority groups such as the Ahmadiyahs, the Syiahs, and the Jemaat GerejaYasmeen (a church community in Bogor). Pluralist Muslim intellectuals such as Ulil Abshar Abdala, Guntur Romli, Nong Mahmada, and Abdul Moqsith, from the traditionalist NU tradition, lent their support to this demonstration. They feared the State was leaving the regulation of religiosity (especially in relation to Islamic minority groups) to radical Islamic groups which had strong connections to the local government in several cities in Indonesia such as Bandung, Bogor, Sukabumi, and Kuningan.

The political consolidation of the \#IndonesiaTanpaJIL movement was triggered by the JIL's protest against the national government, which did nothing to prevent the violence toward the Ahmadiyahs by the FPI in Bandung on October 25, 2012, precisely the night of Idul Adha. The following incident was the attack on the Syiah community in Sampang, Madura. This different interpretation on the role of the State in regulating Islam minority groups in Indonesia became the focal point over the conflict. According to the JIL, the phenomenon of State support for the ban of the Ahmadiyahs and the Syiahs symbolizes a betrayal of the religious freedom guaranteed by the Indonesian Constitution. But \#IndonesiaTanpaJIL took on another interpretation that 
related the phenomenon to the fatwa (decree) released by Majelis Ulama Indonesia (Ulama Council Indonesia) in 1980, which banned the Ahmadiyahs and categorized the group's teachings and activities as heresy toward the Islamic religion. In 2008, the national government released a decree signed by three ministries/agencies (Ministry of Religion, Ministry of Internal Affairs, and the State Attorney) that prohibited the Ahmadiyahs from conducting their religious practices.

The last case, after the polemics surrounding MetroTV news and the Ahmadiyahs, was associated with the issue of morality and the acceptance of Islamic fashion. For the JIL, the use of the scarf (hijab and jilbab in Indonesian) is not an obligation and is a cultural interpretation of the Prophet at the time, which could be re-contextualized in different periods. This opinion is becoming one of the major discourses that the \#IndonesiaTanpaJIL movement always problematizes through social media as well as in their public actions. In response to the JIL's discourse on the hijab, \#IndonesiaTanpaJIL's mobilized Twitter and Facebook to publicize their reaction. They even printed out the tweets from JIL figures on leaflets. On the back of these leaflets, they provided a "clarification" to delineate how the Islamic practices of JIL figures were actually misleading.

One example was a leaflet the \#IndonesiaTanpaJIL movement created and distributed, which featured Luthfi Assyaukanie's tweet. In a direct statement, he had said that the hijab is just like a swimsuit, situational in nature. This statement greatly provoked \#IndonesiaTanpaJIL activists. In response, the movement even captured the whole website page, and linked it to the immoral attitude of JIL intellectuals. The issues problematized by the \#IndonesiaTanpaJIL movement are often not related to the contending interpretations over Islamic conceptions toward politics and minority groups, but are usually related to JIL tweets which, for some people, are provocations. They emphasize the JIL's immoral attitude and what they perceive as the modern, Western cultural lifestyle. Interestingly, \#IndonesiaTanpaJIL members also articulated their propaganda based on the appropriation of Western cultural elements, such as hip-hop, fashion styles, and the growing, significant trend of using English in \#IndonesiaTanpaJIL propaganda tweets.

The cases above show the dynamics of counter-discourse in social media, and its effect on public action and protests against state or mass-media institutions. These changes have brought about a new form of Islamic protest, and new models for urban youth. The implications of this changing Islamic religious movement are located in the change in the religious-group mode of authority and in the sites of struggle, along with their logic of political participation. The continuity and transformation of the Islamic movement's cultural forms follow the infrastructure and its socio-political contexts. In Indonesia, the relations between media-technology evolution, political 


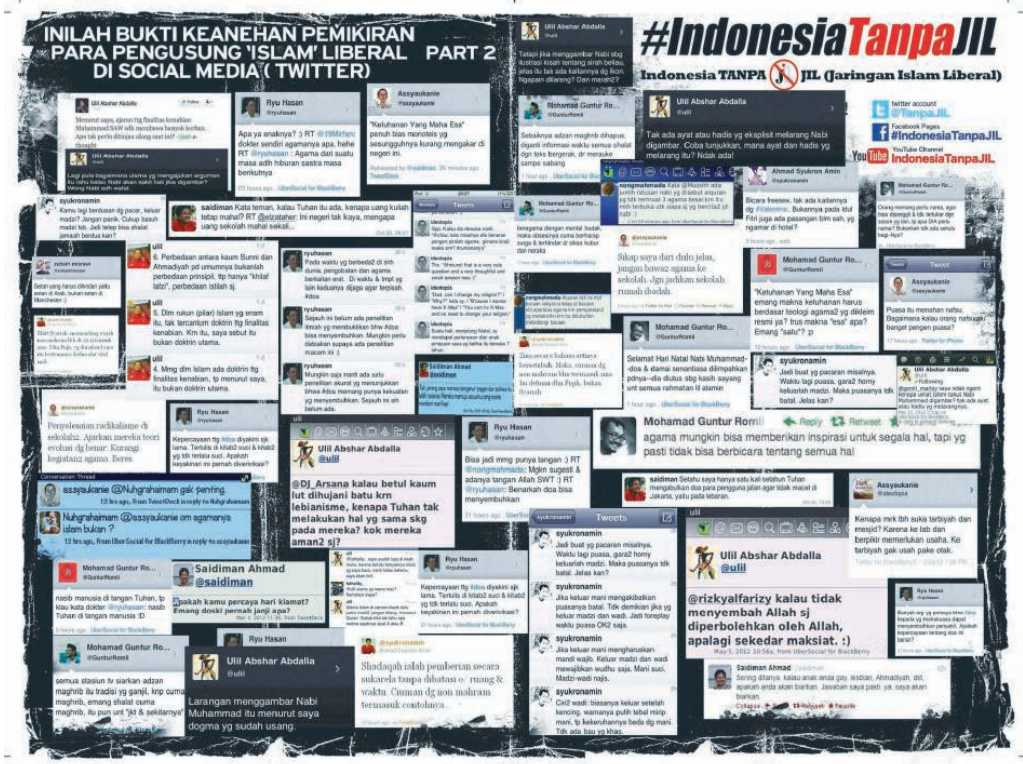

Fig. 2 - A liberal Islam tweet captured through a mobile phone. The image was distributed widely amongst \#IndonesiaTanpaJIL members

changes, and the dynamics within religious and ethnic groups brought subjects into new spheres of socio-religious life, a whole new terrain of identity (Lim 2004). The latest issues that have arisen from this rapid mediated discourse and its contestation indicate the rising discourse of fear among middle-class urban youth and younger Islamic activists in Indonesia, particularly regarding the presence of popular JIL activists and other secular political figures in cyberspace, as well as in urban public spaces such as the national media and state universities.

\section{Popular Culture, Social Media, and Counter-discourse of \#Indonesia- TanpaJIL}

The disputes and polemics in social media and public action influenced \#IndonesiaTanpaJIL to create their own public sphere, based on their own interpretation, which borrowed from various narratives such as the history of the Ummat, citizenship issues, and contemporary popular culture. Political Islam activists, middle-class artists, and urban entrepreneurs from Jakarta and Bandung, brought together through \#IndonesiaTanpaJIL, are playing with revivalist-Islamic discourse and notions of nationalism/citizenship through Indonesian urban pop-culture materiality and market-oriented public spaces. The appropriation of religiosity, citizenship, popular-culture discourse and its 
materiality has created a religious ideology and piety that is articulated in urban public spaces such as (city/town) squares, malls, and high schools. Since 2012, the \#IndonesiaTanpaJIL movement has organized a series of events. In these cases, social-media accounts and blog posts have been (and continue to be) used by \#IndonesiaTanpaJIL activists in their public actions and serve as a means to attract the public, through popular culture elements such as music, celebrity endorsements, gadgets, fashion, and the Internet.

The first move that the \#IndonesiaTanpaJIL movement made to engage popular urban culture/lifestyle was to attend a radio talk on Hard Rock FM Jakarta. Pandji, ${ }^{19}$ a well-known radio anchor, invited Akmal as a speaker. Akmal was asked to explain the problems liberal Islam presented for Indonesia. Pandji also invited JIL activists to the radio show, but their representative failed to turn up at the studio. The talk mostly covered the issue of religious pluralism and the JIL's morally loose interpretations of religion and modern public life. The story of the JIL's refusal to meet at the studio was then repeated at every \#IndonesiaTanpaJIL meeting. The movement's following step was to interview supportive Indonesian celebrities, and upload the video interviews on YouTube. Famous actor Fauzi Badillah was among the national celebrities who lent their support, to the extent that he attended a public event the movement hosted at Dago Square, Bandung. The participation of the underground music community was enlisted as it boosted support to the movement through its influence on the urban youth. Famous underground rock bands such as Purgatory, Melody Maker, and Tengkorak (joined together under the banner association of the One Finger Community) also actively took part in some of the public actions organized by the community.

\begin{tabular}{|l|l|l|l|l|}
\hline No. & \multicolumn{1}{|c|}{ Username } & Followers & Following & \multicolumn{1}{c|}{ Profile } \\
\hline 1 & @FatinSL & 1557465 & 4534 & $\begin{array}{l}\text { Idol contest winner in 2013. Represents young } \\
\text { Muslim popular idols wearing the hijab. }\end{array}$ \\
\hline 2 & @Dewisandra & 1460206 & 753 & $\begin{array}{l}\text { Former artist and singer who, in 2012, started } \\
\text { wearing the hijab. }\end{array}$ \\
\hline 3 & @Yusufmansyur & 1415247 & 9 & Young and famous ustadz/preacher \\
\hline
\end{tabular}

19. Pandji Pragiwaksono is now famous in Indonesian social media as the leading campaigner of Anies Baswedan-Sandiaga Uno, candidate during the 2017 DKI Jakarta governor election. He was often labelled by the Ahok campaign team as a person who was complicit in the fascist and anti-Sino-Indonesians (also anti-China) propaganda of Anies-Sandi supporters during the campaign period. 


\begin{tabular}{|c|c|c|c|c|}
\hline No. & Username & Followers & Following & Profile \\
\hline 4 & (a)agym & 1124041 & 28 & Famous preacher and Islamic entrepreneur \\
\hline 5 & @)ArieKuntung & 942981 & 954 & $\begin{array}{l}\text { Former MTV video jockey/video host. Famous } \\
\text { talk-show host on Indonesian national television }\end{array}$ \\
\hline 6 & @teukuwisnu2 & 861468 & 1249 & Famous soap opera artist (Sinetron) \\
\hline 7 & (a)Felixsiauw & 851279 & 318 & $\begin{array}{l}\text { Famous preacher and self-motivator facilitator. } \\
\text { Affiliated with HizbutTahrir. }\end{array}$ \\
\hline 8 & (a)MaherZein & 845580 & 64 & Famous hip-hop and RnB artist \\
\hline 9 & (a)salimafillah & 218178 & 806 & $\begin{array}{l}\text { Famous preacher from the Tarbiyah Movement } \\
\text { and PKS }\end{array}$ \\
\hline 10 & (a)ALakaUCAY & 50415 & 2911 & $\begin{array}{l}\text { Former band member of Rocketrockers, punk } \\
\text { band from Jakarta }\end{array}$ \\
\hline 11 & (a)Anggiumbara & 16665 & 1081 & Movie director \\
\hline 12 & @)fauzibaadilla & 1380 & 228 & Film actor \\
\hline
\end{tabular}

Table 1 - List of public figures and celebrities of the \#IndonesiaTanpaJIL movement with the number of their "followers" and "following" in November 2012 (retrieved in 2012 by the author through NodXL software application on data from Twitter)

In the following months, the association of fashion distros with Islamic labels such as Islamic Clothes United, Syarikat Kreatifiyah Indonesia, Mujahid Distro, and HijaberstanpaJIL joined the \#IndonesiaTanpaJIL movement by supporting them in merchandise production, as well as creative design competition. Most of the content combined the form of popular culture such as Japanese Manga and the terms/cultural expression of contemporary popular culture. The introduction of an Islamic interpretation then circulated not only through social media but also through the consumption of material merchandise/products. The discourse is thus embedded in what they hear (music), what they wear, and what they do (public action). Their actions, 


\section{KONSERVATIF}
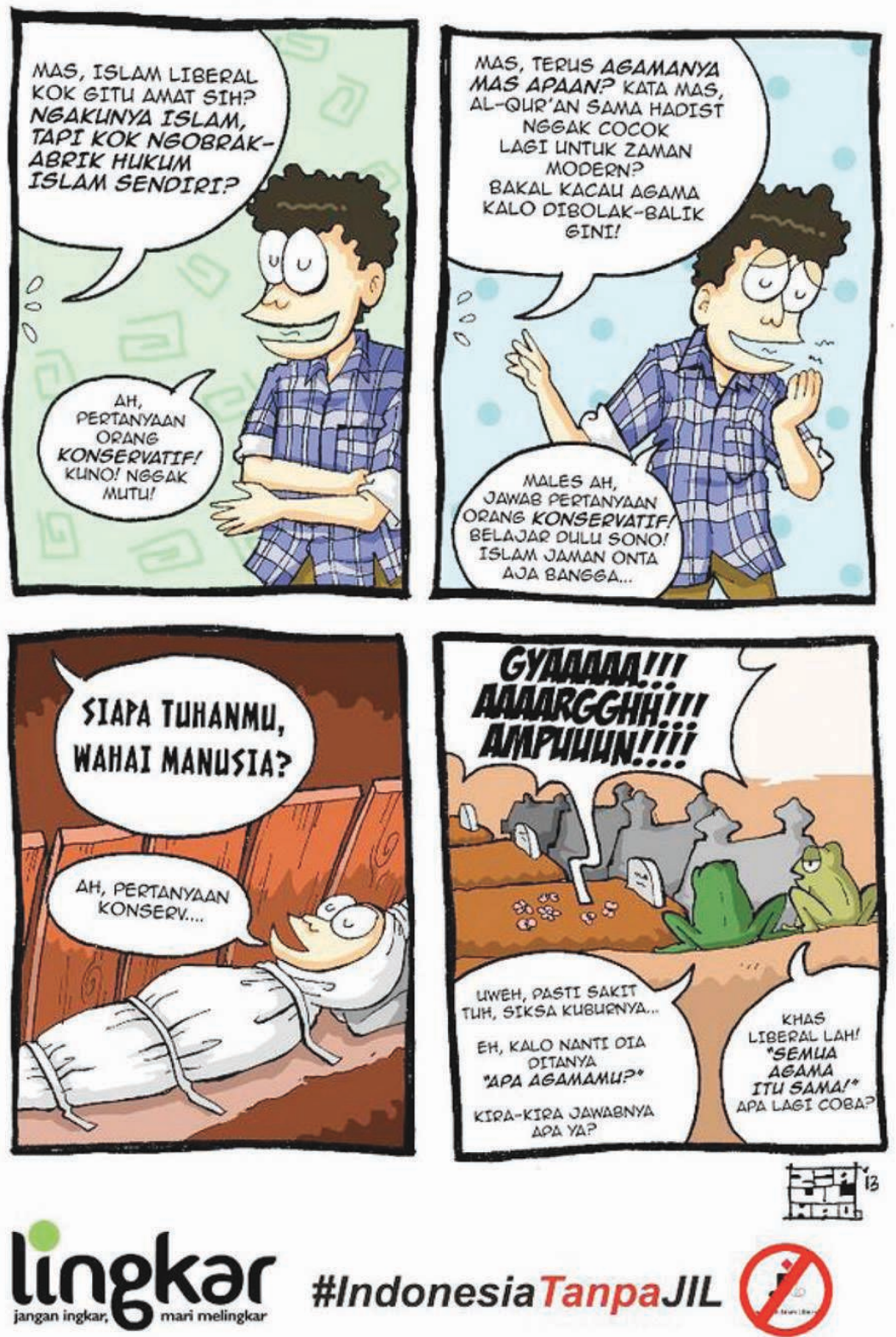

\section{\#IndonesiaTanpaJIL}

Fig. 3 - \#IndonesiaTanpaJIL Comics Distributed through Social Media 


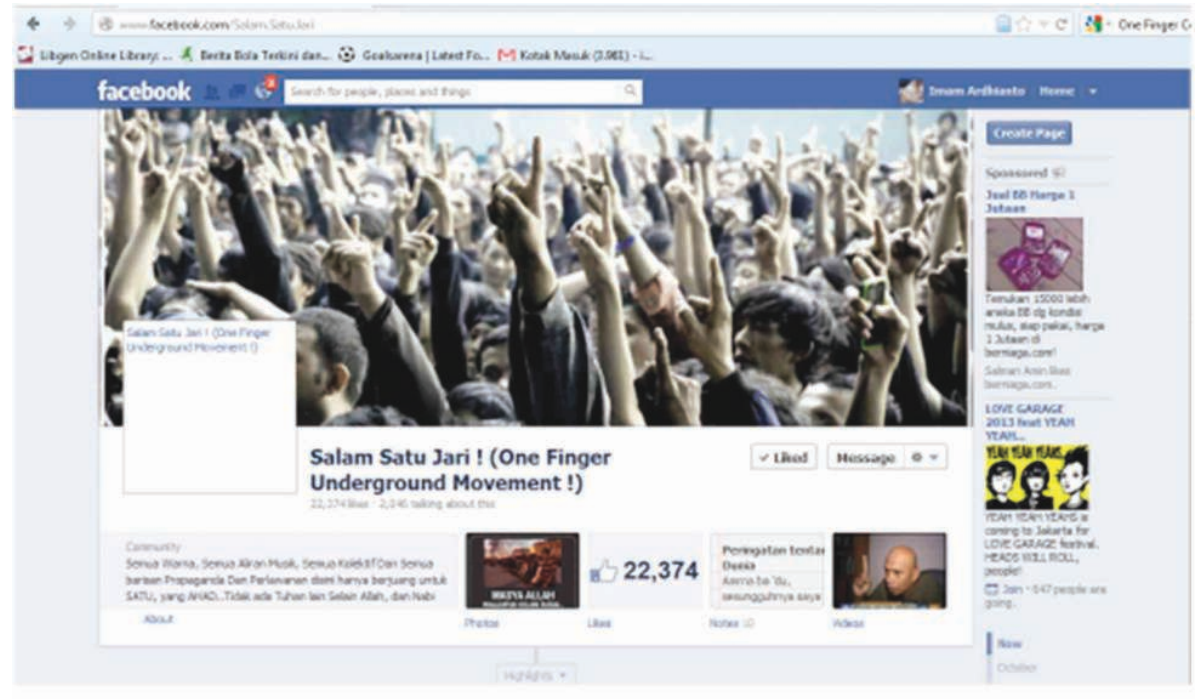

Fig. 4 - Facebook Page of \#IndonesiaTanpaJILOrganization PartnerKomunitas Salam Satu Jari (One Finger Community) Music Movement

which involve all of these materials, can be seen in their various recorded videos on YouTube. Presently there are 30 videos, ${ }^{20}$ including promotional videos, event documentation, and taped past-event talk shows.

On October 28, 2012, the \#IndonesiaTanpaJIL movement hosted a publicaction event at the main square of Depok, a town located to the south of Jakarta. The meeting was attended by participants who represented various groups of the Islamic community such as Underground Tauhid, Ghuroba Militant Chapter Depok, and Tim Peduli Jilbab. Most of the participants came from the Greater Jakarta area and represented activists from Jakarta, Tangerang, Bekasi, and Bogor. Their first action was to hand out flyers explaining the danger of liberal Islam in Indonesia. The event was hosted by two major figures: Hafidz Ary and Akmal Syafril. Having brought a high-performance sound system to the square, they gave a public lecture on the dangers of liberal Islam. Next on the agenda was a speech delivered by a professional master of ceremony (MC) from an eventorganizing company, with the Twitter user account @Okitronic. Mahar Zein's songs and songs from Islamic hip-hop bands from Bandung and Jakarta were played. After the discussion, half-circle lines were formed - males and females being separated into different lines - and the pledge "SumpahPemudaTanpa JIL" was made. Galih, the Depok coordinator of this movement, read the pledge that was created by the \#IndonesiaTanpaJIL community in Solo, on his

20. https://www.youtube.com/user/IndonesiaTanpaJIL 


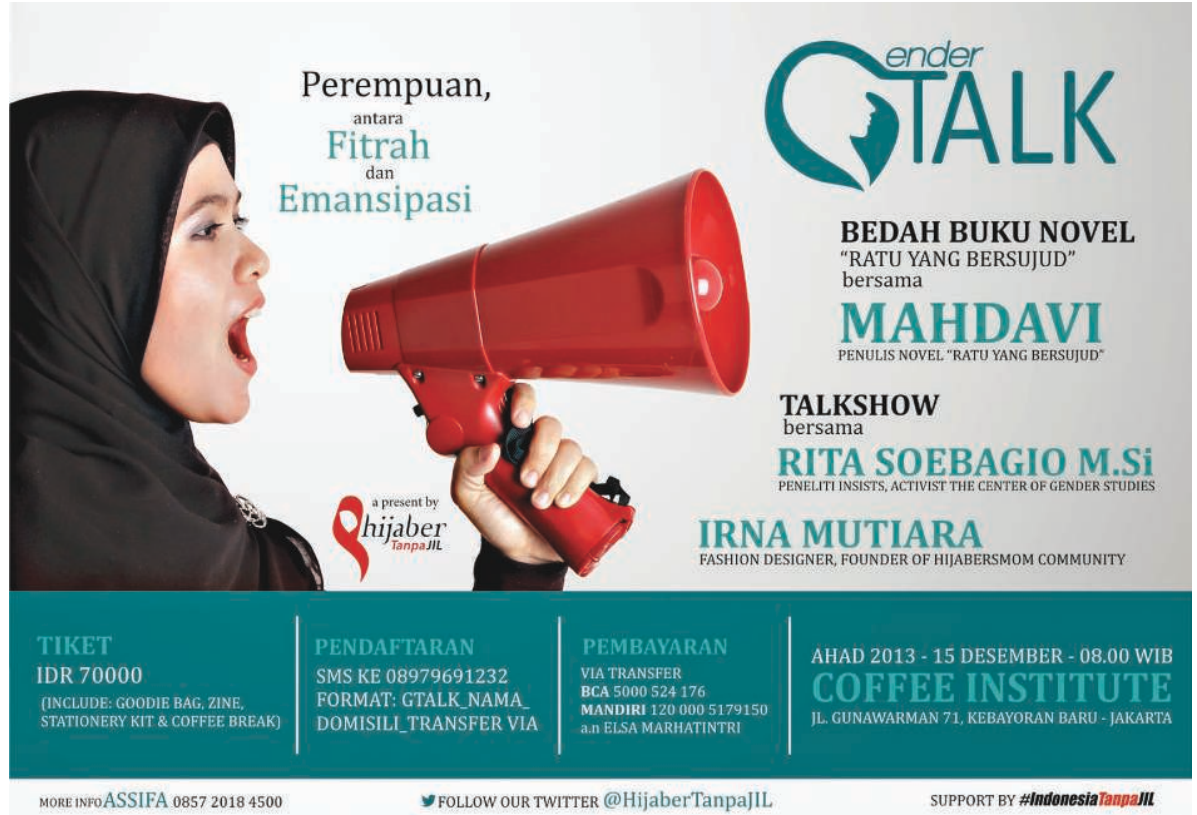

Fig. 5 - Poster of the \#HijaberTanpaJILEvent inviting Rising Middle-class Muslims in Jakarta to attend their Talk Show

\section{Blackberry:}

1. We are the Islamic Youth of Indonesia; acknowledge one motherland, Indonesia, without Islamic Liberal network.

2. We are the Islamic Youth of Indonesia; acknowledge one nation, the nation of Indonesia, without Islamic Liberal groups.

3. We are the Islamic Youth of Indonesia; uphold the language of unity, Indonesian, with the spirits of Tauhid.

Galih, the coordinator of the event, then shouted "Merdeka" (Freedom). This was followed by a shout of collective Syahadat from all the participants, who pointed their fingers to the sky as a symbol of their belief in the one single truth of Islam. News of this action spread all over Indonesia and was spread at the regency level. Sequences from this public action were recorded with digital cameras. A few days later, a video of the event was uploaded onto YouTube, and DVDs were circulated to other members all over Indonesia. The video starts with a statement of Tarbiyah activist@Salimafillah: "Youth is always charming and amazing, even when they sleep they can make social change, but the social change will be more powerful when they are awake."

This public action showcases how public performance in urban space, with new fashion styles and use of gadgets, is becoming important for 


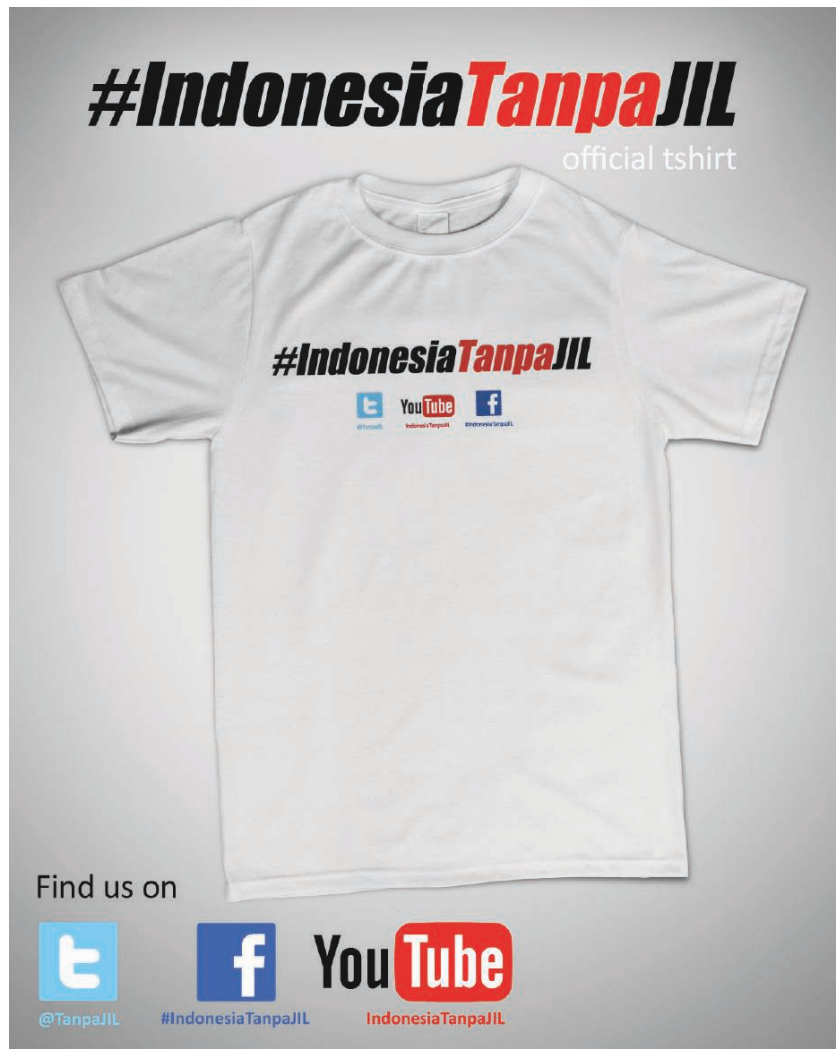

Fig. 6 - \#IndonesiaTanpaJIL T-shirt

\#IndonesiaTanpaJIL. The Internet, high-tech mobile phones, the latest fashion trends, and a Westernized soundscape are part of their strategy to reach out and gain a larger urban-youth following in major Indonesian cities. In another case, they created a booth at the clothes festival in Jakarta, selling their merchandise, handing out flyers, and recording videos featuring national celebrities who supported them.

The changing approach to Islamic discourse circulation and the experiences of Western popular culture among various members of the \#IndonesiaTanpaJIL movement provide us with new portraits of the radical Islamic movement in Indonesia. The urban youth as the target audience and the new urban context that is usually located at the center of circulation of commodities and urban consumption forced this aspect of the movement to adapt to a new situation. The polarization within the movement was visible at the National Congress, which was marked by the attendance of divergent groups that somehow influenced each other (entrepreneurs, musicians, cultural industry workers and the 
younger generation of revivalist groups). The tensions within radicalism thus appeared in the form of the diverse appearances of the Congress participants; nevertheless, there was a salient convergence in their conservative attitudes toward pluralism.

\section{Conclusion}

The context of a post-authoritarian society, new media technology, and rising consumer culture have opened up a new way of interpreting Islam, nationhood, and identity among new activists of political Islam. The \#IndonesiaTanpaJIL political mobilization clearly shows that this new social and urban landscape in Indonesia has influenced the way Islamic identity is being exercised in the public sphere. It is apparent that most of the public actions conducted by the contemporary Islamic movement are always related to their social media discourse, and are presented through mass action with a variety of performances and popular culture attributes, which are actually brought in by the new creative cultural industry in contemporary Indonesia. This phenomenon shows how religiously-conservative popular expression of identity has been shaped by a secular form of popular culture in urban Indonesia. The phenomenon has a significant impact on the understanding of political religious performance in Indonesia: as being exercised through the ambivalence between popular forms and moral-religious discourse.

Social media and the rising economy of the cultural industry are the main factors in the transformation of the way Islamic activists produce, circulate, and consume cultural discourse regarding Islamic values and its relationship with the nation-state. This article reveals a continuity of old, conservative Islamic discourse in discontinuity with regard to its form of cultural attributes. Different segments and generations of Islamists are flourishing through the spread of this movement and are influencing the form and tactics of the contemporary Islamic movement in Indonesia. The close link between online and offline experiences is important in the circulation of the fear of liberalism and, at the same time, in the incorporation of Western popular culture. This ambivalence indicates that to understand the dynamics of religiosity in contemporary Indonesia, there is a need to elaborate on the fluid characteristics of the sacred/religious in the secular space and vice versa in the contemporary Indonesian public sphere. In contemporary Indonesia, the trend toward radicalism is always, at the same time, articulated within the social force that tends to de-radicalize its cultural form as a consequence of market incorporation of religious symbols, identity, and practices, which, surprisingly, always emerge from social media. 


\section{Acknowledgements}

I thank the Center of Anthropological Studies and DIPA-DRPM Universitas Indonesia Research Grant for their research support. The very first draft of this article was presented at the British Sociological Association, Socio-Religion Study Group Conference at Sussex University in July 2014 with generous support from a CASE (Centre Asie du Sud-Est, CNRS, Paris) conference travel grant. I am also grateful to my teachers, mentors, and colleagues at Universitas Indonesia: Tony Rudyansjah, Suraya Afiff, Dave Lumenta, Hestu Prahara, Avianti Azis, and Mujtaba Hamdi for their insights and comments on earlier versions of this article. Finally, I thank Rémy Madinier, Andrée Feillard, Ratna Saptari, Paul Kratoska, Pallavi Narayan and Bart Barendregt for their very valuable comments on my research.

\section{References}

van Bruinessen, M. (2013). Contemporary Developments in Indonesian Islam: Explaining the conservative Turn. Singapore: Institute of Southeast Asian Studies.

Fealy, G., \& White, S. (2008). Expressing Islam: religious life and politics in Indonesia. Singapore: Institute of Southeast Asian Studies.

Feillard, A., Madinier, R. (2011). The end of innocence?: Indonesian Islam and the temptations of radicalism. Translated by Wong Wee. Honolulu: University of Hawai'i Press.

Hadiz, V. R. (2014). "A New Islamic Populism and the Contradictions of Development," Journal of Contemporary Asia 44(1), pp. 125-143.

Hefner, R. W. (2000). Civil Islam: Muslims and democratization in Indonesia. Princeton, NJ: Princeton University Press.

Hirschkind, C. (2006). The ethical soundscape: cassette sermons and Islamic counterpublics. New York: Columbia University Press.

Hirschkind, C., \& Larkin, B. (2008). "Introduction: Media and the Political Forms of Religion," Social Text (96), 1-9 Duke University Press http://www.jstor.org/stable/40283555.

Lim, M. (2004). "Informational terrains of identity and political power: the Internet in Indonesia," Indonesian Journal of Social and Cultural Anthropology 73, pp. 1-11.

Lim, M. (2012). "Clicks, cabs, and coffee houses: Social media and oppositional movements in Egypt, 2004-2011," Journal of Communication 62(2), pp. 231-248.

Meyer, B., \& Moors, A. (2006). Religion, media, and the public sphere. Bloomington: Indiana University Press.

Rakhmani, I. (2017). Mainstreaming Islam in Indonesia: Television, identity, and the middle class. New York: Palgrave Macmillan.

Salvatore, A. (2007). The public sphere: liberal modernity, catholicism, Islam. New York: Palgrave Macmillan. 
